\title{
Willingness to Take COVID-19 Vaccine Among People Most at Risk of Exposure in Southern Ethiopia
}

\section{Bewunetu Zewude Tewodros Habtegiorgis}

Department of Sociology, Wolaita Sodo University, Wolaita Sodo Town, Ethiopia
Correspondence: Bewunetu Zewude Tel +251917104277

Email bewunetuzewude@gmail.com
Background: Acceptance of a vaccine or hesitancy towards it have great public health implications as they partly determine the extent to which people are exposed to infections that could have otherwise been prevented. The present study examined the willingness of primary and secondary school teachers, bank employees, and university instructors in southern Ethiopia to take a Covid-19 vaccine and the factors associated with their willingness.

Methods: An institutional-based cross-sectional study design was used with a quantitative research approach. Primary data were gathered mainly through the use of a survey research method in which a self-administered questionnaire was distributed to randomly selected research participants in Wolaita Sodo town. Data analysis was conducted using statistical techniques, including percentages, frequency distributions, and logistic regression analysis. Results: Research participants generally had a low (46.1\%) willingness to take a COVID-19 vaccine. The main reason for most (37\%) respondents' hesitancy to take the vaccine is found to be the concern over the safety and/or the side effects of the vaccine (37\%), followed by doubt about the vaccine's effectiveness (20.7\%), and lack of adequate information $(12.7 \%)$. Moreover, $38.9 \%$ of survey participants revealed that they would like to take a COVID-19 vaccine other than AstraZeneca whereas $61.1 \%$ of respondents replied that they do not want to take any kind of COVID-19 vaccine. Furthermore, respondents' willingness to take a COVID-19 vaccine is significantly associated with attitude towards the vaccine (OR = $2.830 ; 95 \% \mathrm{CI}=1.834-4.368)$, belief that Covid-19 exists in the study area (OR $=0.221$; $95 \% \mathrm{CI}=0.083-0.589)$, the perception that prevalence and death rate reports of the government are real $(\mathrm{OR}=0.365 ; 95 \% \mathrm{CI}=0.197-0.676)$, status of chronic diseases (OR $=2.883 ; 95 \% \mathrm{CI}=1.039-7.999)$, and having a close relative/friend ever infected by COVID$19(\mathrm{OR}=2.602 ; 95 \% \mathrm{CI}=1.117-6.063)$.

Conclusion: The findings of the research demonstrated that there is generally low willingness to take a COVID-19 vaccine among university instructors, bank employees, and primary and secondary school teachers in southern Ethiopia. Therefore, the federal ministry of health, Ethiopian food and drug controlling agency, the media, and all other concerned organizations should create increased awareness about the safety/side effects issues and the need to take the vaccine.

Keywords: Covid-19, hesitancy, safety, willingness, vaccine

\section{Introduction}

Since its first outbreak in Wuhan province of China in December 2019, the coronavirus pandemic has rapidly spread throughout the world, hampering economic activities, causing changes in the patterns and modes of social interaction, 
affecting political processes, such as by forcing governments of some countries to postpone election activities, and above all, causing the deaths of millions of people. ${ }^{1}$ Increased rate of illness has put increased pressure on the quality of health care in Ethiopia with potential service saturations and severe limitations for poorer households in terms of affordability and accessibility. Ethiopia's health system was not ready for a large-scale crisis: its readiness to deliver routine health services were rated at $55 \%$ of requirements in $2018 .^{2}$ Furthermore, school closures will lead to declines in food intake and nutrition, possibly increase school dropouts, and adversely impact human capital development. ${ }^{3}$ Although countries have been taking various intervention measures to prevent the rapid spreading of the virus, including travel bans and economic lockdowns, declaring states of emergencies to enforce compulsory wearing of face masks, keeping social/physical distance, prohibition of public gatherings, and closure of schools, community spread together with pandemic fatigue have rendered some of these interventions less effective and the need for vaccines is more evident than ever. $^{4}$

The discovery of vaccination is considered as among the great human achievements when it comes to maintaining public health. ${ }^{5-8}$ accination is the most effective way of controlling infectious diseases, yet success is challenged by individuals and groups who choose to delay or refuse vaccines. ${ }^{9}$ Acceptance of a vaccine or hesitancy have great public health implications as these partly determine the extent to which people are exposed to infections that could have otherwise been prevented..$^{10}$ Hesitancy to be vaccinated can be driven by several reasons such as negative medical family experiences that are related to vaccinations of the parents, concerns about the safety of the vaccines, and for religious or ethical reasons. ${ }^{11}$

Research shows that vaccine uptake can be influenced by several factors. ${ }^{12}$ Smith et al. found an association between vaccine uptake and not perceiving vaccines to cause adverse effects, general positive attitude towards vaccination, positive vaccine recommendations, perceiving fewer practical difficulties of vaccination, perceived susceptibility to illness, knowledge about the vaccine, social influences and trust in the health-care profession, and having increased information about the vaccine. Safety concerns, perceived low severity of illness, lack of awareness, and belief in alternative medicine are the common reasons for hesitancy towards vaccination, ${ }^{7}$ whereas health-care professionals' advice, advice from friends and family members, self-protection, belief that vaccination is mandatory, and being responsible have been reported to be the factors affecting the general population's support for vaccination. ${ }^{13}$ Smith et al. found factors such as having previously been vaccinated, perceiving the vaccine to be effective and perception of susceptibility to the disease to be strongly positively associated to uptake of childhood influenza vaccine in England while the factors strongly negatively associated with uptake included perceiving the vaccine to be unsafe, to cause short-term side effects or long-term health problems and believing that yearly vaccination may overload the immune system. A study of the perceived risks of vaccines in European populations ${ }^{14}$ revealed that the primary area of concern was vaccine safety, followed by perceptions of low likelihood of contracting vaccine preventable diseases, perceived low severity of vaccine preventable diseases, beliefs that vaccines do not work, and overall lack of information. Above all, ${ }^{15}$ Rainey et al. found that children's uptake of vaccine is influenced by the socio-economic characteristics of their parents.

According to the health belief model, a person's beliefs about health and health conditions play a significant role in determining his/her health-related behaviors. ${ }^{16}$ The key variables that determine an individual's health behavior include perceived severity of an illness (if believes failure to engage in healthy behavior would have potentially serious consequences), whether a person thinks they are susceptible to certain ill-health conditions, perceived benefits that the person is likely to obtain as a result of engaging in a pro-health behavior, perceived (physical and social) barriers, the extent to which the individual is exposed to external events (information) that prompt a desire to make a health change, and a person's self-efficacy of bringing health-related change; for instance, studies have found a positive effect of increased exposure to vaccination campaigns on adults' vaccination behavior. ${ }^{17-19}$ In addition, a study established how beliefs and values affect the engagement and adherence rate to physical activity among the Kenyan Diaspora living in the USA. ${ }^{20}$

Vaccine hesitancy is believed to be responsible for decreasing vaccine coverage and an increasing risk of vaccine-preventable disease outbreaks and epidemics. ${ }^{5}$ A few available previous studies indicate the low acceptability of Covid-19 vaccination. For instance, studies conducted in Democratic Republic of $\mathrm{Congo}^{8}$ and Saudi Arabia $^{21}$ found low acceptability of Covid-19 vaccination among health-care workers where being male, a doctor (rather than the nurses or other health-care workers), believing that the COVID-19 vaccine should be 
compulsory for all citizens and residents in the country, perceiving a high risk of infection and having positive attitude towards Covid-19 vaccine determined level of acceptability. Furthermore, another recent study ${ }^{22}$ undertaken on patients recovered from Covid-19 infection in Italy also confirmed the low acceptability of the vaccine. In March 2021, Ethiopia received 2.2 million AstraZeneca COVID-19 vaccines which marked the start of the country's COVID-19 vaccination campaign. ${ }^{23}$ Willingness of people in general, and the variation in the level of willingness among various segments of the society in particular, to take the vaccine has not been adequately studied in Ethiopia.

According to the World Bank, ${ }^{24}$ the crisis of COVID19 is causing inequalities, especially between developing and developed countries of the world and without access to the vaccine, the gap will widen further. It therefore calls for the need to ensure access and safe distribution of the vaccine to the people of low income countries. Nevertheless, within a few weeks of hearing that many countries had started to give the vaccine to their people and others are awaiting orders, we heard news that over 20 countries in Europe had stopped giving the vaccine due to reports of adverse problems of blood clots and other related complications such as immune thrombocytopenia (ITP), low platelet counts, internal bleeding, and cerebral venous thrombosis (CVT), reportedly developed by people who have recently received a COVID-19 vaccine in Europe and the USA. ${ }^{25,26}$ Such news might have the effect of increasing hesitancy to take the vaccine, especially among people in developing countries where there is low awareness and high belief and patterns of using alternative medicine.

A study of "Attitude and vaccination status of healthcare workers against hepatitis B infection" in Ethiopia ${ }^{27}$ found that only one-fourth of health professionals received the recommended full dose of the vaccine, where attending infection-prevention training, history of exposure to risky behavior, and long years of work experience have positively affected vaccination status. Findings of previous studies ${ }^{28-33}$ undertaken in Ethiopia on knowledge, attitude, and practice (KAP) show a mix of both high and low knowledge of the various segments of the society towards Covid-19. In addition to the fact that the determinants of vaccine hesitancy and compliance are not fully understood and hence require further study, ${ }^{34}$ researchers found that there is no universally accepted reality regarding the issue and recommended context-specific research. ${ }^{6}$ The objective of the present study was, therefore, to examine willingness to take a Covid-19 vaccine among people working in occupations that put employees relatively at a higher risk of infection with Covid-19 in Wolaita Sodo town, Southern Ethiopia.

\section{Methods}

\section{Research Design}

An institutional-based cross-sectional study was done using a quantitative research approach. Through the survey method, quantitative data were collected from a representative sample of employees working in occupations that are commonly assumed to put workers relatively at a higher risk of being infected by COVID-19.

\section{Selection of Research Participants}

Because of their frequent contact with large gatherings of service seekers and clients, health-care workers, teachers at all levels of education and bank professionals/employees, including bus drivers and their assistants in Ethiopia are assumed to be people relatively at a higher risk of acquiring COVID-19 among other segments of the society. During the period of undertaking the survey, a campaign had already started to give COVID-19 vaccine to healthcare workers in the study area. As a result, health-care workers were not included in the survey. Consequently, primary and secondary level school teachers, university instructors (teaching at Wolaita Sodo University), and bank employees were considered in the study. In order to determine the sample size, the researchers applied Cochran's (1977) formula for calculating sample size of unknown population as:

$$
\mathrm{n}=\frac{\mathrm{z}^{2} \mathrm{pq}}{\mathrm{e}^{2}}=384
$$

Where, $\mathrm{n}$ is the sample size, $\mathrm{z}$ is the selected critical value of desired confidence level, $\mathrm{p}$ is the estimated proportion of an attribute that is present in the population, $q=1-$ $\mathrm{p}$ and $\mathrm{e}$ is the desired level of precision. Then, the final sample units from each institution were chosen on the basis of probability proportionate to size sampling technique.

\section{Research Method and Source of Data}

Primary data were gathered mainly through the use of a survey research method. A self-administered questionnaire was prepared in English, and translated into local (Amharic) language to create a better understanding of the 
questionnaire items among the respondents. Then, data collectors, one possessing a bachelor's degree and two other graduating class students of the sociology department, were trained about the items in the questionnaire, and all the things to be done in the process of data collection. Following this, a permission letter was secured from the concerned body of Wolaita Sodo University. Next, a pilot test was undertaken to prove compatibility of the questionnaire on 30 respondents having similar characteristics with the actual survey population. On the basis of feedback and comments obtained from the baseline survey, slight improvements were made to the instrument of data collection. The same questionnaire, having similar items, was duplicated according to the already determined sample size after consideration of a $5 \%$ addition of questionnaire copies to substitute potential losses before distribution. Finally, the actual data collection activity was held in March, 2021 under the supervision of the principal and co-investigator. During data gathering, data collectors have been clearly instructing respondents about how to fill out the questionnaire. A close follow-up was made by both data collectors and supervisors. Respondents were told to freely raise any question that was unclear to them. The reliability of the instrument was checked through internal consistency of the response items using Cronbach's $\alpha$ while both content and face validity measures were used to maintain its validity.

\section{Instrument Design}

The study involved the collection of quantitative data using an anonymous self-administered questionnaire that consisted of structured questions designed to address the specific research questions. Some of the items in the questionnaire were taken from other studies 8,21 while most of the questions were developed by the researchers. The questionnaire consists of three sections: questions seeking the socio-demographic background of respondents, questions aimed at assessing research participants' willingness to take a COVID-19 vaccine, and the third part which comprises items that examine respondents' attitude towards the vaccine. The first (background) section of the tool comprises variables such as sex, age, education, occupation, chronic illness status, and marital status. In addition, this part also includes questions that aim at measuring respondents' perceptions of COVID-19 and their previous contact or experience with the disease. For instance, respondents were asked if they believe that COVID-19 really exists in Ethiopia in general and the study area in particular, if they think the prevalence and death rate reports of COVID-19 by the government are real, if they have a close relative or friend ever infected by or who died of COVID-19, and whether they believe that they are at a higher risk of being infected by Covid-19, all with response categories of (1) Yes, and (2) No.

The second section of the questionnaire which assesses respondents' willingness to take COVID-19 vaccine consists of questions such as: (1) "Will you take Covid-19 vaccine if it is freely provided by the government?" with response categories of "Yes" and "No", (2) a question that attempts to understand the reasons for respondents who may hesitate to take the vaccine with response categories of "I am concerned about the safety and/or the side effects", "because I believe that I have adequate natural immunity", "I am concerned because I don't think the vaccine will be effective", "I believe that I am not exposed to the disease", "I believe that I can easily withstand the illness if infected by the disease", "I don't think I will need the vaccine due to previous infection, health status or age," among other alternatives. Furthermore, respondents who may respond "Yes" to take the vaccine were also asked when they would like to take the vaccine provided that it is freely available to them, with response categories of "as soon as possible" and "after the vaccine's safety is confirmed". Above all, a question that examines whether respondents are willing to take a COVID-19 vaccine other than AstraZeneca: "Will you take Covid-19 vaccine other than AstraZeneca?" was also included to test if willingness to take the vaccine is related to its brand.

The third section of the questionnaire, with the objective of assessing respondents' overall attitude towards the vaccine, consisted of questions with a four point Likert scale ranging from " 1 = strongly agree" to " $4=$ strongly disagree". The section comprised questions such as: (1) "I will not be taking Covid-19 vaccine until it becomes compulsory by law," (2) "Taking other protective measures is much better than taking COVID-19 vaccine," and "Covid-19 is not such a serious disease that it doesn't require vaccine," among other statements.

\section{Method of Data Analysis}

The questionnaires returned from the respondents were first checked for completeness. The correctly completed ones were then inserted into the software Statistical Package for Social Sciences. Data generated from the software were presented using both descriptive and inferential statistical tools. Data analysis was conducted using 
statistical techniques, including percentages, frequency distributions, mean, standard deviation, and logistic regression analysis. The descriptive statistical techniques were mainly used to present data regarding the frequency and percentage distribution of responses pertaining to respondents' socio-demographic characteristics, willingness to take COVID-19 vaccine, their reasons for hesitancy, and attitude towards COVID-19 vaccine, among others. The logistic regression test was used to examine the association between the socio-demographic characteristics of respondents and their willingness to take a COVID-19 vaccine. In this case, independent variables having a significance level less than or equal to 0.05 were considered to be significantly associated to the dependent variable (willingness to take the vaccine) and those having a significance level of greater than 0.05 were considered as not significantly associated to the dependent variable.

\section{Results}

From the collected questionnaires, 319 (a response rate of $83 \%$ ) were found to be complete and appropriately answered. As presented in Tables 1, 69\% of the respondents are males and $31 \%$ females with the mean age of respondents being 32, $\mathrm{SD}=5.1$. The distribution of respondents in terms of occupation reveals that $38.2 \%$ are bank employees, $32.9 \%$ primary/secondary school teachers, and $28.8 \%$ university instructors. Moreover, most of the survey participants (48.9\%) are BA/BSc degree holders, followed by MA/MSc degree holders (35.4\%). In addition, $68 \%$ of respondents reported to be married while $30.7 \%$ are never married. Furthermore, $89.7 \%$ of respondents do not have any chronic illnesses. Whereas most $(78.1 \%)$ of survey participants believe that COVID19 really exists in Ethiopia, only $69.3 \%$ of them believe that the disease exists in the study area. Importantly, only $39.2 \%$ of respondents think that the prevalence and death rate reports of COVID-19 by the government are real. Data also show a low percentage distribution of respondents who have close relatives/friends ever infected by or who died of COVID-19 (17.2\% and 6.9\%, respectively). It was found that $53.9 \%$ of respondents believe that they are at a higher risk of infected being by COVID- 19 .

\section{Willingness to Take COVID-19 Vaccine}

According to the data presented in Table 2, research participants generally have a low (46.1\%) level of willingness to take COVID-19 vaccine. As presented in Table 3, the main reason for most (37\%) respondents' hesitancy to take
Table I Socio-Demographic Background of Respondents

\begin{tabular}{|c|c|c|}
\hline Variables & Categories & $\begin{array}{l}\text { Frequency } \\
\text { (\%) }\end{array}$ \\
\hline Sex & $\begin{array}{l}\text { Male } \\
\text { Female }\end{array}$ & $\begin{array}{l}220(69 \%) \\
99(31 \%)\end{array}$ \\
\hline Occupation & $\begin{array}{l}\text { University instructor } \\
\text { Primary/secondary } \\
\text { school teacher } \\
\text { Bank employee }\end{array}$ & $\begin{array}{l}92(28.8 \%) \\
105(32.9 \%) \\
122(38.2 \%)\end{array}$ \\
\hline Educational status & $\begin{array}{l}\text { College diploma } \\
\text { BA/BSc degree } \\
\text { MA/MSc degree } \\
\text { PhD or above }\end{array}$ & $\begin{array}{l}40(12.5 \%) \\
156(48.9 \%) \\
113(35.4 \%) \\
10(3.1 \%)\end{array}$ \\
\hline Marital status & $\begin{array}{l}\text { Never married } \\
\text { Married } \\
\text { Divorced }\end{array}$ & $\begin{array}{l}98(30.7 \%) \\
217(68 \%) \\
4(1.3 \%)\end{array}$ \\
\hline $\begin{array}{l}\text { Do you have any chronic } \\
\text { illness (cardiac arrest, } \\
\text { hypertension, diabetes, etc.) }\end{array}$ & $\begin{array}{l}\text { Yes } \\
\text { No }\end{array}$ & $\begin{array}{l}33(10.3 \%) \\
286(89.7 \%)\end{array}$ \\
\hline $\begin{array}{l}\text { Do you believe that COVID- } \\
19 \text { really exists in Ethiopia? }\end{array}$ & $\begin{array}{l}\text { Yes } \\
\text { No }\end{array}$ & $\begin{array}{l}249(78.1 \%) \\
70(21.9 \%)\end{array}$ \\
\hline $\begin{array}{l}\text { Do you believe that COVID- } \\
19 \text { really exists in Wolaita } \\
\text { Sodo town (study area)? }\end{array}$ & $\begin{array}{l}\text { Yes } \\
\text { No }\end{array}$ & $\begin{array}{l}221(69.3 \%) \\
98(30.7 \%)\end{array}$ \\
\hline $\begin{array}{l}\text { Do you think the prevalence } \\
\text { and death rate reports of } \\
\text { COVID-19 by the } \\
\text { government are real? }\end{array}$ & $\begin{array}{l}\text { Yes } \\
\text { No }\end{array}$ & $\begin{array}{l}125(39.2 \%) \\
194(60.8 \%)\end{array}$ \\
\hline $\begin{array}{l}\text { Do you have a close relative } \\
\text { or friend ever infected by } \\
\text { COVID-19? }\end{array}$ & $\begin{array}{l}\text { Yes } \\
\text { No }\end{array}$ & $\begin{array}{l}55(17.2 \%) \\
264(82.8 \%)\end{array}$ \\
\hline $\begin{array}{l}\text { Do you have a close relative } \\
\text { or friend died of COVID-19? }\end{array}$ & $\begin{array}{l}\text { Yes } \\
\text { No }\end{array}$ & $\begin{array}{l}22(6.9 \%) \\
297(93.1 \%)\end{array}$ \\
\hline \multirow[t]{2}{*}{$\begin{array}{l}\text { Do you believe that you are } \\
\text { at a higher risk of being } \\
\text { infected by COVID-19? }\end{array}$} & $\begin{array}{l}\text { Yes } \\
\text { No }\end{array}$ & $\begin{array}{l}172(53.9 \%) \\
147(46.1 \%)\end{array}$ \\
\hline & Total & $319(100 \%)$ \\
\hline
\end{tabular}

the vaccine is found to be the concern over the safety and/ or the side effects of the vaccine, followed by doubt about the vaccine's effectiveness $(20.7 \%)$, lack of adequate information (12.7\%), belief of possessing natural immunity capable of protecting oneself against the disease (6.6\%), reasons related to religion $(5.2 \%)$, and being against all vaccines in general (4.7\%). Furthermore, among the 147 respondents who are willing to take the 
Table 2 Frequency Distribution of Respondents in Terms of Their Willingness to Take COVID-19 Vaccine

\begin{tabular}{|l|l|l|}
\hline Variables/Questions & Categories & $\begin{array}{l}\text { Frequency } \\
\text { (\%) }\end{array}$ \\
\hline $\begin{array}{l}\text { Will you take COVID-19 } \\
\text { vaccine if it is freely } \\
\text { provided by the } \\
\text { government? }\end{array}$ & $\begin{array}{l}\text { Yes } \\
\text { To } \\
\text { Total }\end{array}$ & $\begin{array}{l}147(46.1 \%) \\
172(53.9 \%) \\
319(100 \%)\end{array}$ \\
\hline $\begin{array}{l}\text { When do you like to take } \\
\text { the vaccine? }\end{array}$ & $\begin{array}{l}\text { As soon as possible } \\
\text { After its safety is } \\
\text { confirmed } \\
\text { Total }\end{array}$ & $\begin{array}{l}72(48.9 \%) \\
75(51.1 \%)\end{array}$ \\
\hline $\begin{array}{l}\text { Will you take COVID-19 } \\
\text { other than AstraZeneca? }\end{array}$ & $\begin{array}{l}\text { Yes } \\
\text { No, I do not like to } \\
\text { take any kind of } \\
\text { CoVID-19 vaccine } \\
\text { Total }\end{array}$ & $147(100 \%)$ \\
\hline
\end{tabular}

Table 3 Frequency Distribution of Reasons for Hesitancy to Take the Vaccine

\begin{tabular}{|c|c|c|c|}
\hline \multirow[t]{2}{*}{ Reasons for Vaccine Hesitancy } & \multicolumn{2}{|c|}{ Responses } & \multirow{2}{*}{$\begin{array}{l}\text { Percent } \\
\text { of Cases }\end{array}$} \\
\hline & $\mathbf{N}$ & Percent & \\
\hline $\begin{array}{l}\text { I am concerned about the safety and/ } \\
\text { or the side effects }\end{array}$ & 134 & $37.0 \%$ & $75.3 \%$ \\
\hline $\begin{array}{l}\text { I believe that I have adequate natural } \\
\text { immunity }\end{array}$ & 24 & $6.6 \%$ & $13.5 \%$ \\
\hline $\begin{array}{l}\text { I am concerned because I do not } \\
\text { think the vaccine will be effective }\end{array}$ & 75 & $20.7 \%$ & $42.1 \%$ \\
\hline $\begin{array}{l}\text { I believe that I am not exposed to the } \\
\text { disease }\end{array}$ & 2 & $0.6 \%$ & $1.1 \%$ \\
\hline $\begin{array}{l}\text { I believe that I can easily withstand } \\
\text { the illness if infected by the disease }\end{array}$ & 16 & $4.4 \%$ & $9.0 \%$ \\
\hline $\begin{array}{l}\text { I do not think I will need the vaccine } \\
\text { due to previous infection, health } \\
\text { status or age }\end{array}$ & 3 & $0.8 \%$ & $1.7 \%$ \\
\hline I am against vaccines in general & 17 & $4.7 \%$ & $9.6 \%$ \\
\hline Lack of adequate information & 46 & $12.7 \%$ & $25.8 \%$ \\
\hline Reasons related to belief or religion & 19 & $5.2 \%$ & $10.7 \%$ \\
\hline $\begin{array}{l}\text { I believe that other non-vaccine } \\
\text { preventive mechanisms are sufficient }\end{array}$ & 13 & $3.6 \%$ & $7.3 \%$ \\
\hline $\begin{array}{l}\text { Covid-19 is not that serious concern } \\
\text { in my work or residential area }\end{array}$ & 7 & $1.9 \%$ & $3.9 \%$ \\
\hline Other reasons & 6 & $1.7 \%$ & $3.4 \%$ \\
\hline Total & 362 & $100.0 \%$ & $203.4 \%$ \\
\hline
\end{tabular}

vaccine, $51.1 \%$ disclosed that they would like to take the vaccine after its safety is confirmed while $48.1 \%$ replied that they will take it as soon as possible if it is freely provided to them by the government. Moreover, $38.9 \%$ of
Table 4 Respondents' Perception About the Kind of Person That Needs COVID-19 Vaccine

\begin{tabular}{|c|c|c|c|c|}
\hline \multirow{2}{*}{\multicolumn{2}{|c|}{$\begin{array}{l}\text { Question Categories of } \\
\text { Responses }\end{array}$}} & \multicolumn{2}{|c|}{ Responses } & \multirow{2}{*}{$\begin{array}{l}\text { Percent } \\
\text { of Cases } \\
50.8 \% \\
\end{array}$} \\
\hline & & $\frac{N}{162}$ & $\begin{array}{l}\text { Percent } \\
33.0 \%\end{array}$ & \\
\hline $\begin{array}{l}\text { What kind of } \\
\text { person/s do you } \\
\text { think need } \\
\text { COVID-19 } \\
\text { vaccine? }\end{array}$ & $\begin{array}{l}\text { Everyone } \\
\text { People with high } \\
\text { risk of exposure } \\
\text { to the disease } \\
\text { Elderlies } \\
\text { People with } \\
\text { other health } \\
\text { complications } \\
\text { People naturally } \\
\text { having weaker } \\
\text { immune system } \\
\text { I do not know } \\
\text { Others }\end{array}$ & $\begin{array}{l}162 \\
90\end{array}$ & $\begin{array}{l}11.0 \% \\
2.9 \%\end{array}$ & $\begin{array}{l}16.9 \% \\
4.4 \%\end{array}$ \\
\hline \multicolumn{2}{|l|}{ Total } & 491 & $100.0 \%$ & $153.9 \%$ \\
\hline
\end{tabular}

survey participants revealed that they would like to take a COVID-19 vaccine other than AstraZeneca whereas $61.1 \%$ of respondents replied that they do not want to take any kind of COVID-19 vaccine.

Data presented in Table 4 reveal that most (33\%) respondents perceive COVID-19 vaccine is appropriate for everyone, followed by $18.3 \%$ who think that the vaccine is more appropriate for people with a high risk of exposure to the disease, $13 \%$ for elderlies.

Tables 5 and 6 present data regarding the attitude of survey participants about COVID-19 vaccines. Accordingly, it is found that respondents have reasonably favorable attitudes $(\mathrm{M}=2.3, \mathrm{SD}=0.77)$ towards the vaccine. Most respondents believe that taking other

Table 5 Descriptive Statistics of Attitude Towards COVID-19 Vaccines

\begin{tabular}{|l|l|l|}
\hline Statements & Mean & SD \\
\hline $\begin{array}{l}\text { I will not be taking Covid-19 vaccine unless I am } \\
\text { compelled by law }\end{array}$ & 2.4 & 1.14 \\
$\begin{array}{l}\text { Taking other protective measures is much better } \\
\text { than taking COVID-19 vaccine } \\
\text { Covid-19 is not such a serious disease that it does } \\
\text { not require vaccine }\end{array}$ & 2.8 & 1.09 \\
$\begin{array}{l}\text { I believe that the side effects of Covid-19 vaccine } \\
\text { outweigh its immunizing advantages } \\
\text { It is better to be infected by COVID-19 than taking } \\
\text { the vaccine }\end{array}$ & 1.9 & 1.03 \\
Aggregated statistic & 1.03 \\
\hline
\end{tabular}


Table 6 Likert Scale Statistics of Respondents' Attitudes Towards COVID-19 Vaccine

\begin{tabular}{|c|c|c|c|c|}
\hline Statements & $\begin{array}{l}\text { Strongly } \\
\text { Agree }\end{array}$ & Agree & Disagree & $\begin{array}{l}\text { Strongly } \\
\text { Disagree }\end{array}$ \\
\hline I will not be taking Covid-19 vaccine until it becomes compulsory by law & $81(25.4 \%)$ & $115(36.1 \%)$ & $35(11 \%)$ & $88(27.6 \%)$ \\
\hline Taking other protective measures is much better than taking COVID-19 vaccine & $45(14.1 \%)$ & $83(26 \%)$ & $67(21 \%)$ & $124(38.9 \%)$ \\
\hline Covid-19 is not such a serious disease that it does not require vaccine & $90(28.2 \%)$ & $132(4 \mid .4 \%)$ & $4 I(12.9 \%)$ & $56(17.6 \%)$ \\
\hline $\begin{array}{l}\text { I believe that the side effects of Covid-19 vaccine outweigh its immunizing } \\
\text { advantages }\end{array}$ & $67(21 \%)$ & II I (34.8\%) & $51(16 \%)$ & $90(28.2 \%)$ \\
\hline It is better to be infected by COVID-I 9 than taking the vaccine & $|4|(44.2 \%)$ & $113(35.4 \%)$ & $19(6 \%)$ & $46(14.4 \%)$ \\
\hline
\end{tabular}

protective measures (wearing mask, keeping physical/ social distance, frequently washing hands, etc.) is much better than taking a COVID-19 vaccine $(\mathrm{M}=2.8, \mathrm{SD}=$ 1.09). In addition, data presented in Table 6 reveal that $36 \%$ of respondents agree and $25.4 \%$ strongly agree on the statement that "I will not be taking Covid-19 vaccine until it becomes compulsory by law". In addition, $44.2 \%$ strongly agree and $35.4 \%$ agree that it is better to be infected by Covid-19 than taking the vaccine.

\section{Factors Associated to Willingness to Take a COVID-I 9 Vaccine}

Results of the logistic regression presented in Table 7 show that respondents' willingness/hesitancy to take COVID-19 vaccine is significantly associated with attitude towards the vaccine $(\mathrm{OR}=2.830 ; 95 \% \mathrm{CI}=1.834-4.368)$, belief that Covid-19 exists in the study area $(\mathrm{OR}=0.221$; $95 \% \mathrm{CI}=0.083-0.589)$, the perception that prevalence and death rate reports of the government are real $(\mathrm{OR}=0.365$; $95 \% \mathrm{CI}=0.197-0.676)$, status of chronic diseases ( $\mathrm{OR}=$ $2.883 ; 95 \% \mathrm{CI}=1.039-7.999)$, and having a close relative/friend ever infected by COVID-19 (OR $=2.602 ; 95 \%$ $\mathrm{CI}=1.117-6.063)$. In other words, respondents who believe COVID-19 exists in the study area are 4.5 times more likely to take the vaccine or the odds of respondents not to take the vaccine increases by 0.221 for those who believe that COVID-19 exists in the study area. In addition, the odds of respondents not to take the vaccine increases by 0.365 for those who think that prevalence and death rate reports of COVID-19 are real. Or respondents who think that prevalence and death rate reports by the government are real are 2.7 times more likely to take the vaccine than those who do not believe. Furthermore, respondents who have close relatives or friends ever infected by COVID-19 are 2.6 times more likely not to take the vaccine. Above all, for the respondents having chronic diseases, the odds of not taking the vaccine is found to be 2.88. On the other hand, sex $(\mathrm{OR}=1.023$; 95\% CI: $0.545-1.919)$, marital status $(\mathrm{OR}=10.641 ; 95 \%$ CI: $0.825-137.305)$, educational status $(\mathrm{OR}=0.326 ; 95 \%$ CI: $0.045-2.347)$, occupation $(\mathrm{OR}=1.147 ; 95 \% \mathrm{CI}$ : 0.501-2.623), the belief that Covid-19 exists in Ethiopia $(\mathrm{OR}=1.665 ;$ 95\% CI: 0.506-5.477), perception of being at a higher risk of being infected by Covid-19 (OR = 0.524; 95\% CI: $0.263-1.046)$, age (OR $=0.950$; 95\% CI: 0.897-1.007), and having a close friend/relative who died of Covid-19 (OR $=0.696$; 95\% CI: 0.217-2.235) are all not significantly associated with willingness/hesitancy to take Covid-19 vaccine.

\section{Discussion}

Vaccination is the most effective way of controlling infectious diseases, but success is challenged by individuals and groups who choose to delay or refuse vaccines. ${ }^{9}$ Vaccine hesitancy is believed to be responsible for decreasing vaccine coverage and an increasing risk of vaccinepreventable disease outbreaks and epidemics. ${ }^{5}$ The present research generally aimed at assessing the willingness to take a COVID-19 vaccine of people in selected occupational categories that are presumably at a higher risk of exposure to COVID-19 due mainly to their daily contact with relatively large gatherings of clients or service seekers. In this case, teachers of primary and secondary schools, university instructors, and bank employees were systematically selected to participate in the study. The results of the study indicated that research participants have low (46.1\%) willingness to take a COVID-19 vaccine because of the concern about the safety of the vaccine (37\%), doubt about the vaccine's effectiveness (20.7\%), lack of adequate information (12.7\%), belief of possessing natural immunity capable of protecting oneself against the disease $(6.6 \%)$, reasons related to religion $(5.2 \%)$, and being against all vaccines in general (4.7\%). Furthermore, it is also found that from the total of survey 
Table 7 Logistic Regression Estimates of Factors Associated with Willingness to Take a COVID-19 Vaccine

\begin{tabular}{|c|c|c|c|c|c|c|c|}
\hline \multirow[t]{2}{*}{ Variables } & \multirow[t]{2}{*}{ Categories } & \multicolumn{3}{|c|}{$\begin{array}{l}\text { Will You Take } \\
\text { Covid-19 Vaccine } \\
\text { if it is freely } \\
\text { Provided by the } \\
\text { Government? }\end{array}$} & \multicolumn{3}{|c|}{$\begin{array}{l}\text { Logistic Regression Test } \\
\text { Statistics }\end{array}$} \\
\hline & & Yes & No & Total & OR & $95 \% \mathrm{Cl}$ & $P$ value \\
\hline Sex & $\begin{array}{l}\text { Male } \\
\text { Female }\end{array}$ & $\begin{array}{l}102 \\
45\end{array}$ & $\begin{array}{l}118 \\
54\end{array}$ & $\begin{array}{l}220 \\
99\end{array}$ & 1.023 & $0.545-1.919$ & 0.945 \\
\hline Occupation & $\begin{array}{l}\text { Bank employee } \\
\text { Primary/sec. school } \\
\text { teacher } \\
\text { University instructor }\end{array}$ & $\begin{array}{l}53 \\
51 \\
43\end{array}$ & $\begin{array}{l}69 \\
54 \\
49\end{array}$ & $\begin{array}{l}122 \\
105 \\
92\end{array}$ & I. 147 & $0.50 \mathrm{I}-2.623$ & 0.746 \\
\hline Marital status & $\begin{array}{l}\text { Never married } \\
\text { Married } \\
\text { Divorced }\end{array}$ & $\begin{array}{l}47 \\
97 \\
3\end{array}$ & $\begin{array}{l}51 \\
120 \\
1\end{array}$ & $\begin{array}{l}98 \\
217 \\
4\end{array}$ & $10.64 \mid$ & $0.825-137.305$ & 0.070 \\
\hline Educational status & $\begin{array}{l}\text { Diploma } \\
\text { BA/BSc Degree } \\
\text { MA/MSc Degree } \\
\text { PhD \& above }\end{array}$ & $\begin{array}{l}30 \\
58 \\
53 \\
6\end{array}$ & $\begin{array}{l}10 \\
98 \\
60 \\
4\end{array}$ & $\begin{array}{l}40 \\
156 \\
113 \\
10\end{array}$ & 0.326 & $0.045-2.347$ & 0.266 \\
\hline Do you believe that COVID-19 really exists in Ethiopia? & $\begin{array}{l}\text { Yes } \\
\text { No }\end{array}$ & $\begin{array}{l}134 \\
13\end{array}$ & $\begin{array}{l}115 \\
57\end{array}$ & $\begin{array}{l}249 \\
70\end{array}$ & 1.665 & $0.506-5.477$ & 0.401 \\
\hline $\begin{array}{l}\text { Do you believe that COVID-19 really exists in Wolaita } \\
\text { Sodo town (study area)? }\end{array}$ & $\begin{array}{l}\text { Yes } \\
\text { No }\end{array}$ & $\begin{array}{l}129 \\
18\end{array}$ & $\begin{array}{l}92 \\
80\end{array}$ & $\begin{array}{l}221 \\
98\end{array}$ & $0.221 * *$ & $0.083-0.589$ & 0.003 \\
\hline $\begin{array}{l}\text { Do you think the prevalence and death rate reports of } \\
\text { COVID-19 by the government are real? }\end{array}$ & $\begin{array}{l}\text { Yes } \\
\text { No }\end{array}$ & $\begin{array}{l}82 \\
65\end{array}$ & $\begin{array}{l}43 \\
129\end{array}$ & $\begin{array}{l}125 \\
194\end{array}$ & $0.365 * *$ & $0.197-0.676$ & 0.001 \\
\hline $\begin{array}{l}\text { Do you have a close relative or friend ever infected by } \\
\text { COVID-19? }\end{array}$ & $\begin{array}{l}\text { Yes } \\
\text { No } \\
\text { No }\end{array}$ & $\begin{array}{l}29 \\
118 \\
44\end{array}$ & $\begin{array}{l}26 \\
146 \\
103\end{array}$ & $\begin{array}{l}55 \\
264 \\
147\end{array}$ & $2.602 *$ & $1.117-6.063$ & 0.027 \\
\hline Do you have any chronic disease? & $\begin{array}{l}\text { Yes } \\
\text { No }\end{array}$ & $\begin{array}{l}12 \\
135\end{array}$ & $\begin{array}{l}21 \\
151\end{array}$ & $\begin{array}{l}33 \\
286\end{array}$ & $2.883^{*}$ & $1.039-7.999$ & 0.042 \\
\hline $\begin{array}{l}\text { Do you have a close relative or friend who died of } \\
\text { COVID-19? }\end{array}$ & $\begin{array}{l}\text { Yes } \\
\text { No }\end{array}$ & $\begin{array}{l}13 \\
134\end{array}$ & $\begin{array}{l}9 \\
163\end{array}$ & $\begin{array}{l}22 \\
297\end{array}$ & 0.696 & $0.217-2.235$ & 0.542 \\
\hline $\begin{array}{l}\text { Do you believe that you are at a higher risk of being } \\
\text { infected by Covid-19? }\end{array}$ & $\begin{array}{l}\text { Yes } \\
\text { No }\end{array}$ & $\begin{array}{l}103 \\
44\end{array}$ & $\begin{array}{l}69 \\
103\end{array}$ & $\begin{array}{l}172 \\
147\end{array}$ & 0.524 & $0.263-1.046$ & 0.067 \\
\hline Age & & & & & 0.950 & $0.897-1.007$ & 0.085 \\
\hline Attitude towards COVID-19 vaccine & & & & & $2.830 * * *$ & I.834-4.368 & 0.000 \\
\hline
\end{tabular}

Note: Predicted probability for the ORs above is based on membership for "no". *** $\mathrm{P}<0.00 \mathrm{I},{ }^{*} * \mathrm{P}<0.0 \mathrm{I},{ }^{*} \mathrm{P}<0.05$.

Abbreviations: OR, odd ratio; $\mathrm{Cl}$, confidence interval.

participants who are willing to take the vaccine, $51.1 \%$ replied that they will take the vaccine after its safety is confirmed while only $48.9 \%$ said they would like to take the vaccine as soon as possible. The findings of the present research are consistent with the findings of previous studies conducted in other parts of the world. For instance, a research undertaken in Saudi Arabia ${ }^{21}$ found that only half of the study participants were willing to be vaccinated of which $49.71 \%$ intended to have the vaccine as soon as it becomes available in the country, while $50.29 \%$ would delay until the vaccine's safety is confirmed. In addition, another recent study ${ }^{22}$ undertaken on patients recovered 
from Covid-19 infection in Italy also confirmed the low acceptability of the vaccine where previous infection, health status or age, doubt over the effectiveness of the vaccine, concerns over the safety/side effects of the vaccine, and being against vaccines in general are the main reasons for vaccine hesitancy. Above all, the finding of the present study is also consistent with a related previous study conducted in Africa. For instance, a study among health-care workers in Democratic Republic of Congo found a very low acceptability (27.7\%) of COVID-19 vaccine. $^{8}$

Having undertaken the research within the context in which some countries, especially those in Europe and the USA, started to give COVID-19 vaccine to their people, we have also assessed whether our respondents will be willing to take a COVID-19 vaccine other than AstraZeneca. Accordingly, we have found that $38.9 \%$ of survey participants are willing to take other brands of the vaccine other than AstraZeneca while 61.1\% replied that they do not want to take any kind of COVID-19 vaccine. Perhaps, this might be due to the then prevailing discoveries of certain safety/side effect concerns over AstraZeneca vaccine which led many countries in Europe to suspend giving the vaccine to their people. For instance, ${ }^{25,26}$ over 20 countries in Europe have stopped giving the vaccine due to reports of adverse problems of blood clots and other related complications such as immune thrombocytopenia (ITP), low platelet counts, internal bleeding, or cerebral venous thrombosis (CVT), reportedly developed by people who have recently taken a COVID-19 vaccine. Although most of such countries have been planning to resume giving the vaccine due to updates from concerned agencies regarding the absence of strong evidence that the observed side effects are necessarily linked to the vaccine, the spread of the former information across the world could have its own influence on the acceptability of the vaccine, especially that of AstraZeneca.

The results of the present research have also shown that respondents' willingness/hesitancy to take a COVID19 vaccine is significantly associated with their attitude towards the vaccine $(\mathrm{OR}=2.830 ; 95 \% \mathrm{CI}=1.834-4.368)$, belief that Covid-19 exists in the study area $(\mathrm{OR}=0.221$; 95\% CI $=0.083-0.589)$, the perception that prevalence and death rate reports of the government are real $(\mathrm{OR}=$ $0.365 ; 95 \% \mathrm{CI}=0.197-0.676)$, status of chronic diseases $(\mathrm{OR}=2.883 ; 95 \% \mathrm{CI}=1.039-7.999)$, and having a close relative/friend ever infected by COVID-19 (OR = 2.602;
95\% CI $=1.117-6.063$ ). Findings of previous related studies revealed that the acceptability of a COVID-19 vaccine is associated with sex, occupation, belief that COVID-19 vaccine should be compulsory for all citizens and residents in a country, perception of high risk of infection, and having positive attitude towards COVID-19 vaccine. $^{8,21,22}$ Older age, public work exposure, and previous flu shots were factors associated with positive attitudes towards both COVID-19 and influenza vaccinations. ${ }^{13}$ Smith et al. found an association between vaccine uptake and not perceiving vaccines to cause adverse effects, general positive attitude towards vaccination, positive vaccine recommendations, perceiving fewer practical difficulties of vaccination, perceived susceptibility to illness, knowledge about the vaccine, social influences and trust in the health-care profession, having increased information about the vaccine. ${ }^{7}$ Safety concerns, perceived low severity of illness, lack of awareness, and belief in alternative medicine are the common reasons for hesitancy towards vaccination. ${ }^{13}$ Smith et al. found factors such as having previously been vaccinated, perceiving the vaccine to be effective and perceiving to be susceptible to the disease to be strongly positively associated to uptake of childhood influenza vaccine. A study of the perceived risks of vaccines in European populations ${ }^{14}$ revealed that the primary area of concern was vaccine safety, followed by perceptions of low likelihood of contracting vaccine preventable diseases, perceived low severity of vaccine preventable diseases, beliefs that vaccines do not work, and overall lack of information. According to the Health Belief Model, the key variables that determine an individual's health behavior include perceived severity of an illness (if believes failure to engage in healthy behavior would have potentially serious consequences), whether a person thinks they are susceptible to certain ill-health conditions, perceived benefits that a person is likely to obtain as a result of engaging in a pro-health behavior, perceived (physical and social) barriers, the extent to which the individual is exposed to external events (information) that prompt a desire to make a health change, and a person's self-efficacy of bringing health-related change. ${ }^{17-19}$

\section{Conclusions}

The findings of the research demonstrated that there is generally low willingness to take a COVID-19 vaccine among university instructors, bank employees, and primary/secondary school teachers in southern Ethiopia. 
Among others, concern over the safety/side effects of the vaccine and lack of trust about the effectiveness of the vaccine were the main reasons that led to such high hesitancy to the vaccine among the research participants. Furthermore, the finding that some percentages of the respondents are willing to take a COVID-19 vaccine other than AstraZeneca might be linked to the recently heard information regarding the side effects of the vaccine. Due to the nature of the work which requires routine contact with service seekers often gathered at a space, participants of the survey are not only at a higher risk of infection to COVID-19 but also they are more likely to transmit the disease to other large numbers of people. With Ethiopia being affected by the second wave of the pandemic, together with the country's very limited economic capacity to purchase vaccines, it should at least cover its high risk population with the few COVID-19 vaccines obtained through international aid. With such high levels of hesitancy, however, the effort may be challenged. Therefore, the federal ministry of health, Ethiopian food and drug controlling agency, the media, and all other concerned organizations should create increased awareness about the safety/side effects issues and the need to take the vaccine.

\section{Data Sharing Statement}

The data used to support the findings of this study are available from the corresponding author upon reasonable request.

\section{Ethical Approval and Consent to Participate}

The researchers obtained ethical approval from the ethical approval committee of Wolaita Sodo University. In addition, a formal letter was secured from the department of sociology, Wolaita Sodo University. An informed verbal and written consent was obtained by informing the research participants about the objectives and rationale of undertaking the research. Furthermore, upon collecting data, the names of the research participants were not written on the interviewer administered questionnaire in order to keep their personal identity anonymous. Moreover, research participants were informed ahead about the possibility of withdrawing from the study in case the need arises at any time. Above all, the study was carried out in accordance with the Declaration of Helsinki.

\section{Acknowledgment}

We would like to extent our gratitude to duplication unit staff of Wolaita Sodo University for their unreserved help in the process of duplicating the questionnaires. In addition, we are highly thankful to graduating class (MA program) students of the sociology department at Wolaita Sodo University for willingly taking part in the data collection activities of the research. Finally, all respondents who have willingly devoted their time in filling the questionnaires and providing interviews also deserve appreciation.

\section{Funding}

There is no funding to report.

\section{Disclosure}

The authors declare that there are no conflicts of interest.

\section{References}

1. Sim MR. The COVID-19 pandemic: major risks to healthcare and other workers on the front line. Occupational and Environmental Medicine. 2020;77(5):281-282. doi:10.1136/oemed-2020-106567

2. United Nations Ethiopia (UN). Socio-Economic Impact of Covid-19 in Ethiopia. Addis Ababa: ONE UN Assessment; 2020.

3. UNICEF Ethiopia. Socio-economic impacts of COVID-19; 2020, Available from: https://www.unicef.org/ethiopia/media/2741/file/ Socioeconomic\%20impacts\%20of\%20COVID-19.pdf. Accessed May 14, 2021.

4. Prüb_BM. Current State of the First COVID-19 Vaccines. Vaccines. 2021;9:30. doi:10.3390/vaccines 9010030

5. Papagiannis D. The Lack of Vaccine in the Recent COVID-19 Pandemic and the Silence of Anti-vaccination Activists. Hellenic J Nursing. 2020;59(4):348-352.

6. Deml MJ, Jafflin K, Merten S, et al. Determinants of vaccine hesitancy in Switzerland: study protocol of a mixed-methods national research programme. BMJ Open. 2019;9(11):e032218. doi:10.1136/ bmjopen-2019-032218

7. Yaqob O, Clarke CS, Sevdalis N, Chataway J. Attitudes to vaccination: a critical review. Soc Sci Med. 2014;112:1-11. doi:10.1016/j. socscimed.2014.04.018

8. Nzaji KM, Ngombe KL, Mwamba NG, et al. Acceptability of Vaccination against Covid-19 among healthcare workers in the Democratic Republic of the Congo. Pragmatic Observational Res. 2020;11:103-109. doi:10.2147/POR.S271096

9. Paterson P, Paterson P, Meurice F, Stanberry LR, Glismann S, Rosenthal SL. Vaccine hesitancy and healthcare providers. Vaccine. 2016;34:6700. doi:10.1016/j.vaccine.2016.10.0425

10. Dyda A, King C, Dey A, Leask J, Dunn AG. A systematic review of studies that measure parental vaccine attitudes and eliefs in childhood vaccination. BMC Public Health. 2020;1253:1-8.

11. Thorsteinsson EB, Draper A, Lykins D. To Vaccinate or Not: the Relative Impact of Attitudes toward Autism Spectrum Disorders and the Ability to Interpret Scientific Information on Vaccination Decisions. Int J Environ Res Public Health. 2020;17(7):2542. doi:10.3390/ijerph17072542

12. Smith L, Amlot R, Weinman J, Yiend J, Rubin J. A systematic review of factors affecting vaccine uptake in young children. Vaccine. 2017;35(45):6059-6069. doi:10.1016/j.vaccine.2017.09.046 
13. Smith LE, Webster KR, Weinman J, Amlot R, Yiend J. Psychological factors associated with uptake of the childhood influenza vaccine and perception of post-vaccination side-effects: a cross-sectional survey in England. Vaccine. 1936-1945;2017(35).

14. Karafillakis E, Larson HJ. The benefit of the doubt or doubts over benefits? A systematic literature review of perceived risks of vaccines in European populations. Vaccine. 2017;35(37):4840-4850. doi:10.1016/j.vaccine.2017.07.061

15. Rainey JJ, Watkins M, Ryman TK, Sandhu P, Bo A, Banerjee K. Reasons related to non-vaccination and under-vaccination of children in low and middle income countries: findings from a systematic review of the published literature, 1999-2009. Vaccine. 2011;29 (46):8215-8221. doi:10.1016/j.vaccine.2011.08.096

16. Boskey E. Health Belief Model, 2020, Available from https://www. verywellmind.com/health-belief-model-3132721. Accessed May 14, 2021.

17. Jones CL, Jensen JD, Scherr CL, Brown NR, Christy K, Weaver J. The Health Belief Model as an Explanatory Framework in Communication Research: exploring Parallel, Serial, and Moderated Mediation. Health Commun. 2015;30(6):566-576. doi:10.1080/ 10410236.2013.873363

18. Hermann A, Hall A, Proietto A. Using the Health Belief Model to explore why women decide for or against the removal of their ovaries to reduce their risk of developing cancer. BMC Women's Health. 2018;18:184. doi:10.1186/s12905-018-0673-2

19. Frankenfield KM, "Health belief model of breast cancer screening for female college students". Master's Theses and Doctoral Dissertations; 2009. 258. Available from: http://commons.emich. edu/theses/258. Accessed May 14, 2021.

20. Wambua JM. Using the Health Belief Model to Study Health Perceptions of Kenyans in the United States. Global J Human Soc Sci. 2018;18:3

21. Qattan AMN, Alshareef N, Alsharqi O, Al Rahahleh N, Chirwa GC, Al-Hanawi MK. Acceptability of a COVID-19 Vaccine Among Healthcare Workers in the Kingdom of Saudi Arabia. Front Med. 2021;8:644300. doi:10.3389/fmed.2021.644300

22. Gerussi V, Peghin M, Palese A, et al. Vaccine Hesitancy among Italian Patients Recovered from COVID-19 Infection towards Influenza and Sars-Cov-2 Vaccination. Vaccines. 2021;9(2):172. doi: $10.3390 /$ vaccines 9020172

23. AllAfrica. Ethiopia Receives the First Astra Zeneca Covid-19 Vaccine; 2021, Available from https://allafrica.com/stories/ 202103070285.html. Accessed May 14, 2021.

24. World Bank (WB). COVID-19: vaccines for Developing Countries, 2021, Available from: https://live.worldbank.org/covid-19-vaccinesdeveloping-countries?fbclid=Iw AR3 w Z 7 JEjUuquIe f8iCtMZc0bFYAoEMRT7_AP7eOUu3NMlgEIDVkcLYr7E. Accessed May 14, 2021
25. Science. 'It's a very special picture.' Why vaccine safety experts put the brakes on AstraZeneca's COVID-19 vaccine; 2021, Available from: ttps:/www.sciencemag.org/news/2021/03/it-s-very-specialpicture-why-vaccine-safety-experts-put-brakes-astrazeneca -s-covid19?fbclid=IwAR342kTxQHfUMQa9RTZnFcB_MweG0 Ifgcu4syAfzOHhTuIuLmNe9D4KI5c.

26. The New York Times. A Few Covid Vaccine Recipients Developed a Rare Blood Disorder, 2021, Available from: https://www.nytimes. com/2021/02/08/health/immune-thrombocytopenia-covid-vaccineblood.html. Accessed May 14, 2021.

27. Akibu M, Nurgi S, Mesgfin T. Attitude and Vaccination Status of Healthcare Workers against Hepatitis B Infection in a Teaching Hospital, Ethiopia, Scientifica. Scientifica. 2018;2018:1-8. doi:10. 1155/2018/6705305

28. Bekele F, Sheleme T, Fekadu G, Bekele K. Patterns and associated factors of COVID-19 knowledge, attitude, and practice among general population and health care workers: a systematic review. SAGE Open Med. 2020;8:2050312120970721. doi:10.1177/2050312120970721

29. Wake AD. Knowledge, Attitude, Practice, and Associated Factors Regarding the Novel Coronavirus Disease 2019 (COVID-19) Pandemic. Infect Drug Resist. 2020;13:3817-3832. doi:10.2147/ IDR.S275689

30. Abate H, Mekonnen CK. Knowledge, Attitude, and Precautionary Measures towards COVID-19 among Medical Visitors at the University of Gondar Comprehensive Specialized Hospital Northwest Ethiopia. Infect Drug Resist. 2020;13:4355-4366. doi:10.2147/IDR.S282792

31. Degu A, Nibret G, Gebrehana H, Getie A, Getne B. Knowledge and Attitude Towards the Current Pandemic Corona Virus Disease and Associated Factors Among Pregnant Women Attending Antenatal Care in Debre Tabor General Hospital Northwest Ethiopia: an Institutional-Based Cross-Sectional Study. Int $J$ Womens Health. 2020;13:61-71. doi:10.2147/IJWH.S285552

32. Akalu Y, Ayelign B, Molla MD. Knowledge, Attitude and Practice Towards COVID-19 Among Chronic Disease Patients at Addis Zemen Hospital, Northwest Ethiopia. Infect Drug Resist. 2020;13:1949-1960. doi:10.2147/IDR.S258736

33. Kassa AM, Mekonnen AM, Yesuf KA, Tadesse AW, Bogale GG. Knowledge level and factors influencing prevention of COVID-19 pandemic among residents of Dessie and Kombolcha City administrations, North-East Ethiopia: a population-based cross-sectional study. BMJ Open. 2020;10:e044202. doi:10.1136/bmjopen-2020044202

34. Larson HJ, Jarrett C, Eckersberger E, et al. Understanding vaccine hesitancy around vaccines and vaccination from a global perspective: a systematic review of published literature, 2007-2012. Vaccine. 2014;32(19):2150-2159. doi:10.1016/j.vaccine.2014.01.081
Pragmatic and Observational Research

\section{Publish your work in this journal}

Pragmatic and Observational Research is an international, peerreviewed, open access journal that publishes data from studies designed to reflect more closely medical interventions in realworld clinical practice compared with classical randomized controlled trials (RCTs). The manuscript management system is completely online and includes a very quick and fair peer-review system. Visit http://www.dovepress.com/testimonials.php to read real quotes from published authors. 